\title{
FURTHER EXPERIENCES WITH THE MALE-TOAD PREGNANCY TEST USING EUROPEAN SPECIES
}

\author{
BY \\ MAGNUS HAINES, H. P. FERREIRA, J. W. LAW, AND AUDREY MAY \\ From Chelsea Hospital for Women, London
}

(RECEIVED FOR PUBLICATION SEPTEMBER 19, 1953)

The satisfactory reports on the Galli Mainini male toad test for pregnancy which have been published from nearly every part of the world (Cowie, 1948 ; Bhaduri, 1951) show that the test can be performed on species of toads or frogs indigenous to the district where the laboratory is situated. In England and Europe the toads Bufo bufo (syn. $B$. vulgaris) and $B$. calamita and the frog Rana esculenta are used for the test. Favourable results with these species have been reported by Hinglais and Hinglais (1948), Haines and Ferreira (1949), Klopper and Frank (1949), Frazer and Wohlzogen (1949), and Bach, Szmuk, Robert, and Klinger (1949). In a later paper Frazer and Wohlzogen (1951) described a method for estimating urinary gonadotrophin using $B$. bufo.

\section{Modifications of the Earlier Technique}

The principle and the technique of the test which have already been described for a South American species (Haines, 1948) are readily adapted to European species and the technical details of modifications in procedure which we found necessary for the new species have been described by Law (1949).

The toads available weighed only 15-25 g. and the volume of urine injected was reduced to $2 \mathrm{ml}$., i.e. $1 \mathrm{ml}$. per $10 \mathrm{~g}$. body weight. Because there was an injection mortality of up to $40 \%$ a modified purification method was tried (Scott, 1940) and thereafter no deaths occurred from injections. Brody (1949) adopted a similar method with good results. This procedure, by concentrating the hormone, increases the sensitivity of the test, and these advantages outweigh any loss of time spent in the elution process.

The test is performed (by tradition) on an early morning specimen of urine, but positive results are obtainable on specimens collected at other times. Quantitative tests are performed on untreated urine diluted with distilled water. The patient's serum ( $2 \mathrm{ml}$.) instead of urine gives consistently good results. It seems preferable to use serum for dilution tests and doubtful cases because the concentration of hormone in the urine may fluctuate, depending on various factors, including the rate of urinary output.

\section{Reading of the Test}

The end-point is taken as the appearance of spermatozoa in a specimen of toad's urine usually collected from the cloaca. Spermatozoa may be found in less than one hour after injection. Our tests were read at the end of three hours-or four if negative at three. Under circumstances where a weak positive response was to be expected (see below) readings were taken at five and six hours. A weak positive is denoted by a delayed response of the test animal and by the presence of relatively few sperms per low-power field. Increasing numbers of sperms may be found at the end of the fourth and fifth hours when only two or three per field were found at the end of the third hour. In our experience few sperms per field, in the absence of a delayed response, indicate exhaustion of the test animal. The urine of positive reactors was found clear of spermatozoa within two days of the injection. All animals used in the series were tested (and found negative) before a test was begun.

A series of 1,023 male toad tests using this technique was carried out between April, 1949, and May, 1950. This report is based upon the experimental series augmented by information collected from the routine use of the test in the three years following.

\section{Results in Pregnancy}

Routine pregnancy tests were carried out on 732 samples of urine. There were 238 negative results : six of these may be designated false negative. All provided positive results after the first negative. Five subsequently aborted at or before the twelfth week and the sixth case went to term. There were no false results among 494 positive tests. All of these were confirmed clinically.

ROUTINE PREGNANCY TESTS

\begin{tabular}{ll|c|c|c|c|c}
\hline & & \multicolumn{3}{|c|}{ Weeks after Missed Period } & \multirow{2}{*}{ Total } \\
\cline { 3 - 5 } & & 1st & 2nd & $3-6$ & $7-14$ & \\
\hline Positive tests & $\ldots$ & 32 & 70 & 314 & 78 & 494 \\
Negative , &. & 14 & 32 & 121 & 71 & 238 \\
\hline
\end{tabular}


Most of the tests $(59.4 \%$ ) were done about three to six weeks after the first missed period, but there were 102 positives in the first two weeks. The earliest confirmed positive response was obtained two days after the period was due in a patient admitted to hospital for colporrhaphy. All six false negative results were obtained in the groups three to six weeks after the missed period.

\section{Controls}

Control tests were made on 40 gynaecological and obstetrical patients. Negative controls were taken on 20 patients who were in hospital for a diagnostic curettage which excluded normal pregnancy. Positive controls were provided by 20 patients attending ante-natal clinics from the twentieth to the twenty-fourth weeks of pregnancy. Toads were given injections of proprietary gonadotrophins in 68 instances. It was found that freshly caught toads would respond to doses of 5 to 10 i.u. It required 20 to 25 i.u. to evoke a response in those kept in captivity and used frequently throughout the summer. Even this loss of sensitivity did not interfere with the reliability of the test in routine work.

A small number of tests were run in parallel with other species, viz., Bufo arenarum, Xenopus laevis (female), and Rana esculenta.

CONTROL TESTS USING OTHER SPECIES

\begin{tabular}{|c|c|c|c|}
\hline $\begin{array}{l}\text { No. of } \\
\text { Tests }\end{array}$ & $\begin{array}{l}\text { Control } \\
\text { Animals }\end{array}$ & Results & $\begin{array}{l}\text { Bufo bufo } \\
\text { Results }\end{array}$ \\
\hline 36 & B. arenarum & 35 correct & 36 correct \\
\hline 62 & $X$. laevis (female) & $\begin{array}{l}\text { 1 fase negative } \\
59 \text { correct }\end{array}$ & 62 correct \\
\hline 12 & R. esculenta & $\begin{array}{l}3 \text { false negatives } \\
12 \text { correct }\end{array}$ & $\begin{array}{l}11 \text { correct } \\
1 \text { false negative }\end{array}$ \\
\hline
\end{tabular}

\section{Ectopic Pregnancy}

The following interesting results were obtained in 30 patients admitted to hospital because of suspected ectopic pregnancy:

\begin{tabular}{|c|c|c|}
\hline Final Diagnosis & Positive & Negative \\
\hline 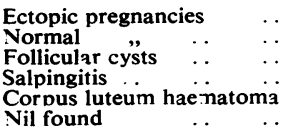 & $\begin{array}{r}11 \\
4 \\
- \\
=\end{array}$ & $\begin{array}{l}2 \\
3 \\
2 \\
1 \\
7\end{array}$ \\
\hline
\end{tabular}

The final diagnosis was made either at laparotomy or by examination under anaesthesia. In 11 of the 13 true ectopic gestations the male toad test was positive. Its value in this condition lies in its rapidity. It can usually be completed between admission and operation. A negative re- action does not exclude this diagnosis but indicates, in agreement with the clinical findings, tha $\overrightarrow{\overrightarrow{5}}$ the pregnancy has been interrupted (Aschein 1950).

\section{Threatened Abortion}

In this group there were 19 patients who gave negative results and abortion followed in each case. Positive results were obtained in 25 patients:In some of these a weak positive response (see above) was obtained and this indicated a poot prognosis. Abortion within seven to 14 days was the rule. But we are not yet able to form a res liable opinion in every case of this kind becaused we have no means of measuring accurately the absolute "weakness" or "strength" of a test an the number of cases examined is too small.

\section{Other Results}

Four tests were performed in one fatal case of chorion carcinoma and positive results were $\mathrm{ob}_{\overrightarrow{0}}$ tained up to a dilution of 1 in 500 .

Negative tests were given on four samples of urine from two patients with testicular teratomas More than 100 tests were made on eight cases of hydatidiform mole. Before evacuation of the mole the titre was found to be not less than 1 if 200 and as high as 1 in 600 in one case. Norma? pregnancies never yielded a positive test in dilu흘 tions greater than 1 in 100 . In normal pregnancy the test is usually negative within 100 hours of complete expulsion of the placenta. In three patients the tests remained positive for two, five and eight months respectively following evacuas tion of a mole and in the apparent absence of. intra-uterine chorionic tissue as judged by repeated negative curettage. Dilution tests were consis ently negative. Two cases of syncytial ender metritis (syncytioma) gave negative results. One case of acute hydramnios at 16 weeks' gestation gave a positive result in a dilution of only 1 䎡 50 and a positive test to a titre of 1 in 150 wa recorded in one case of hyperemesis gravidarum Positive results were obtained in six samples maternal blood while the results were negative using corresponding samples of foetal cord blood.

\section{Discussion}

The indigenous species of male toad $B$. bufo has proved to be an eminently satisfactory test anima $\vec{\Phi}$. Using the method of concentrating the urinary gonadotrophin we have achieved a degree of acce्ष racy $(99.2 \%)$ comparable with all other standa pregnancy tests. This agrees with the findings of Frazer and Wohlzogen (1950). The toad is ngt 
subject to vagaries of spermatogenesis of the common frog $R$. temporaria (Cei, 1944) or of the male Xenopus as observed by Robbins and Parker (1948) and by Schwabacher (1951). Neither does it yield false positive tests when injected with distilled water, adrenaline, jaundiced urine, or urine containing an excess of F.S.H. as reported in different species of frogs.

False negative results in pregnancy tests are often attributed to performing the test too early in the pregnancy when the urinary gonadotrophin level would be low or to the variation of hormone levels in individual pregnancies (Robbins and Parker, 1948). The high incidence of false negatives recorded by Klopper and Frank (1949) and by Diczfalusy and Westman (1950) can probably be so attributed. Our false negatives occurred between the third and sixth week of pregnancy and five of these patients, though free from symptoms when the test was performed, subsequently aborted, suggesting that gonadotrophin excretion is irregular in these unstable pregnancies.

The rapidity of the test is particularly useful in assisting the diagnosis of ectopic pregnancy where early operation may be indicated. A result may be had in two or three hours, and in our small group 11 out of 13 true ectopics gave a correct positive result.

In cases of hydatidiform mole the test is applicable to diagnosis and follow-up. Many observations may be made-for example, in one case weekly tests were carried out over a period of eight months with very little trouble and expense.
The diagnostic titre for both moles and chorion epitheliomas appears to be about 1:200, though many molar pregnancies will be encountered in which the hormonal concentration is considerably less. Syncytioma sometimes confused clinically and histologically with chorion carcinoma invariably yields negative tests. This agrees with the observation that chorionic gonadotrophin is elaborated by the cytotrophoblast (Wislocki. Dempsey, and Fawcett, 1948).

We have found the test cheap, simple to perform, accurate and rapid, and therefore particularly useful in the study of abnormalities of pregnancy as well as in routine pregnancy diagnosis.

We are grateful to members of the clinical staff of Chelsea Hospital for Women and to many others for submitting specimens for the test and for making available the clinical data of their patients.

\section{REFERENCES}

Ascheim, S. (1950). An. Fac. Med. Montevideo, 35, 696.
Bach, I., Szmuk, I., Robert, L., and Klinger, B. (1949). Lancet, 1, 124.

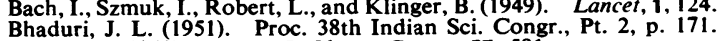
Brody, H. (1949). Amer. J. Obstet. Gynec., 57, 581.

Cei, G. (1944). Monit. zool. ital., 54, Suppl.

Cowie, A. T. (1948). Pregnancy Diagnosis Tests: A Review. Commonwealth Agricultural Bureaux Joint Publ. No. 13. Great Britain.

Diczfalusy, E., and Westman, A. (1950). Acta obstet. gynec. scand.. $30,308$.

Frazer, J. F. D., and Wohlzogen, F. X. (1949). Lancet, 2, 306.

C (1950). Brit. med. J., 2, 330. (1951). J. Physiol., Lond., 113, 322.

Haines, M. (1948). Nature, Lond. $162,416$.

Haines, M. (1948). N P (1949). Ibid, 164, 668.

Hinglais, H., and Hinglais, M. (1948). C. R. Soc. Biol. Paris, 142, 460.

Klopper, A., and Frank, H. (1949). Lancet, 2, 9.

Law, J. W. (1949). Bull. Inst. med. Lab. Tech., 14, 175.

Robbins, S. L., and Parker, F. (1948). Endocrinology, 42, 237.

Schwabacher, H. (1951). Med. Press, 226, 82.

Scott, L. D. (1940). Brit. J. exp. Path, 21, 320

Wislocki, G. B., Dempsey, E. W., and Fawcett, D. W. (1948). Obstet. gynec. Surv., 3, 604. 